\title{
Meiotic DNA replication checkpoint control in fission yeast
}

\author{
Hiroshi Murakami ${ }^{1}$ and Paul Nurse \\ Cell Cycle Laboratory, Imperial Cancer Research Fund, London WC2A 3PX, UK
}

In eukaryotes, the DNA replication checkpoint prevents entry into mitosis when DNA replication is incomplete and is crucial for maintaining genomic integrity. Much less is known about equivalent controls that operate during meiosis. Here, we show that a DNA replication checkpoint control operates during meiosis in fission yeast. The mitotic checkpoint Rad genes and the Cds1 protein kinase are required for the DNA replication checkpoint during meiosis, with Cds1 playing a more prominent role than it does during mitosis. When DNA replication is blocked, the checkpoint maintains Cdc2 tyrosine 15 phosphorylation keeping Cdc2 protein kinase activity low and preventing onset of meiosis I. Additionally, there is a second checkpoint acting during meiosis that is revealed if cells are prevented from maintaining Cdc2 tyrosine 15 phosphorylation when DNA replication is blocked. Such cells arrest with high Cdc2 protein kinase activity and separated spindle pole bodies, an arrest state similar to that observed in mitotic budding yeast cells when DNA replication is incomplete. This second checkpoint is meiosis specific and may reflect processes occurring only during meiosis such as increased recombination rates, an extended duration of nuclear division, or homolog chromosome pairing.

[KeyWords: Checkpoint; meiosis; cdc2; tyrosine phosphorylation; Schizosaccharomyces pombe]

Received July 6, 1999; revised version accepted August 18, 1999.

Faithful replication of DNA in S phase and its accurate segregation at mitosis result in each daughter cell receiving a full complement of genetic information. Checkpoint mechanisms operate during the mitotic cell cycle and ensure that if DNA replication is incomplete or if DNA is damaged, then the subsequent mitosis is blocked (Hartwell and Weinert, 1989). In the fission yeast Schizosaccharomyces pombe, the checkpoint Rad genes $\left(\mathrm{rad} 1^{+}, 3^{+}, 9^{+}, 17^{+}, 26^{+}\right.$, and hus $\left.1^{+}\right)$are required for both the DNA replication and DNA damage checkpoints (Al-Khodairy and Carr 1992; Enoch et al. 1992; Jimenez et al. 1992; Rowley et al. 1992; Al-Khodairy et al. 1994). Strains with these mutations are checkpoint defective, allowing entry into mitosis when DNA is damaged or its replication is incomplete. A number of these genes are conserved in budding yeast and metazoan cells and are thought to be involved in the checkpoint controls operating in these organisms (Rhind and Russell 1998a; Weinert 1998b).

Two fission yeast protein kinases, Cds1 and Chk1, act downstream of the checkpoint Rad proteins and are required to communicate checkpoint signals to the mechanisms that control mitosis (Walworth et al. 1993; Murakami and Okayama 1995; Walworth and Bernards

${ }^{1}$ Corresponding author.

E-MAIL murakami@icrf.icnet.uk; FAX 0171-269-3610.
1996; Lindsay et al. 1998). The Cds1 kinase appears to be required for proper recovery from a DNA replication checkpoint block, but is not required for the DNA damage checkpoint control (Murakami and Okayama 1995), whereas the Chk1 kinase is primarily involved in the DNA damage checkpoint control (Walworth et al. 1993). The protein kinase activity of Cds1 and the phosphorylation of Chk1 are dependent on the checkpoint Rad proteins (Walworth and Bernards 1996; Lindsay et al. 1998), and homologs of Cds1 and Chk1 have been found in other organisms (Fogarty et al. 1997; Peng et al. 1997; Sanchez et al. 1997; Sibon et al. 1997; Kumagai et al. 1998; Matsuoka et al. 1998; Blasina et al. 1999). In addition, Crb2/Rhp9, which is structurally related to budding yeast Rad9, has a very similar role to Chk1 (Saka et al. 1997; Willson et al. 1997). Both the DNA replication and DNA damage checkpoint controls block mitosis via the cyclin-dependent kinase (CDK) Cdc2 complexed with the B-type cyclin Cdc13 (Enoch and Nurse 1990; Rhind et al. 1997). The Cdc2-Cdc13 protein kinase is fully activated at the onset of mitosis by dephosphorylation of Cdc2 tyrosine 15 (MacNeill and Nurse 1997). Phosphorylation of Cdc2 on tyrosine 15 is catalyzed by both the Weel and Mik1 tyrosine kinases, and dephosphorylation is carried out by the Cdc25 tyrosine phosphatase and to a lesser extent by the Pyp3 phosphatase (MacNeill and Nurse 1997). The DNA replication checkpoint can be abolished by (1) a semi-dominant Cdc2 
(Enoch and Nurse 1990), (2) overexpressing $c d c 25^{+}$to reduce the level of phosphorylation of Cdc2 on tyrosine 15 (Enoch and Nurse 1990), (3) inactivating the Weel and Mik1 kinases (Lundgren et al. 1991), or (4) use of a Cdc2Y15F mutant (Enoch et al. 1991; Rhind and Russell 1998b). These studies strongly suggest that the DNA replication checkpoint acts through tyrosine 15 phosphorylation of $\mathrm{Cdc} 2$, although this conclusion has been controversial (Knudsen et al. 1996; Rhind and Russell 1998b). The linkage between the checkpoint Rad genes and the cell cycle machinery is likely to be provided by both Cds1 and Chk1. Inhibition of DNA replication activates Cds1, which subsequently acts through Wee1 and Cdc25 to stop cell cycle progression (Boddy et al. 1998; Zeng et al. 1998), whereas Chk1 is physically associated with Cdc25 and appears to phosphorylate Cdc25 (Furnari et al. 1997) and Weel (Nurse 1997; O'Connell et al. 1997).

Our understanding of meiotic checkpoint controls is much less well developed than mitotic checkpoint controls. In budding yeast, Mec1, a counterpart of $S$. pombe Rad3, is involved in meiotic recombination (Kato and Ogawa 1994) and is required for the meiotic DNA replication checkpoint (Stuart and Wittenberg 1998). Budding yeast mutants defective in the completion of meiotic recombination arrest in prophase, and this arrest is dependent on certain mitotic DNA damage checkpoint genes including $M e c 1$, suggesting the existence of a meiotic recombination checkpoint (Lydall et al. 1996). A number of gene products that operate in mitotic checkpoint controls have been found to be localized in various metazoan cells undergoing meiosis. For example, the human homolog of $S$. pombe Rad1 is found on both synapsed and unsynapsed chromosomes during meiotic prophase (Freire et al. 1998), whereas the Rad3-related ATM protein kinase is located along paired meiotic chromosomes, and the ATR protein kinase is found distributed along unpaired meiotic chromosomes (Keegan et al. 1996; Barlow et al. 1998). ATM-deficient mice are infertile because meiotic cells arrest in prophase I during spermatogenesis or oogenesis (Xu et al. 1996; Barlow et al. 1998). A human homolog of Chk1 co-localizes with ATR along meiotic chromosomes, and its protein level and localization are dependent on the ATM protein (Flaggs et al. 1997). In Drosophila, MEI-41, a homolog of S.pombe Rad3, is required for normal levels of meiotic recombination in oocytes (Hari et al. 1995).

In this report we carry out a systematic study of the DNA replication checkpoint control during meiosis in fission yeast. We establish that checkpoint Rad and Cds1 proteins are required for the meiotic DNA replication checkpoint, and also that phosphorylation of Cdc2 tyrosine 15 is maintained during a block over DNA replication, keeping $\mathrm{Cdc} 2$ protein kinase activity low. However, if Cdc2 is artificially dephosphorylated on tyrosine leading to a rise in $\mathrm{Cdc} 2$ protein kinase activity, progression through meiotic nuclear division still remains blocked, suggesting that there is a second control operative in meiotic cells. Therefore, we propose that the replication checkpoint signal pathway in meiosis has two targets; one is phosphorylation of Cdc2 tyrosine 15, and the other is an unidentified downstream target independent of Cdc2 phosphotyrosine regulation.

\section{Results}

\section{A DNA replication checkpoint operates in meiosis}

When the completion of DNA replication is prevented in mitotically dividing fission yeast cells with the inhibitor hydroxyurea (HU), the onset of the subsequent mitosis is blocked. To test whether a similar DNA replication checkpoint control is operative during meiosis, fission yeast diploid cells heterozygous for mating-type genes $\left(h^{-} / h^{+}\right)$were induced to undergo meiosis by shifting them from late log phase to nitrogen-free medium $(-\mathrm{N})$. HU was added at different concentrations at various times after the medium change (Fig. 1A, left). Premeiotic DNA replication began $\sim 2 \mathrm{hr}$ after the medium change as judged by FACS (data not shown). Completion of meiosis was monitored by counting the number of nuclei in each ascus after $17 \mathrm{hr}$, a time by which meiosis and sporulation is largely complete. Blocks over meiotic nuclear division prevent the formation of multinucleate cells. Cells with only one nucleus were observed in concentrations of HU above $6 \mathrm{~mm}$ added within $2 \mathrm{hr}$ of the medium change (Fig. 1A left). This suggests that a DNA replication checkpoint is operative in fission yeast meiotic cells. The effects of various mutants known to be defective in the DNA replication or DNA damage checkpoints during the mitotic cell cycle were then tested. In the absence of $\mathrm{HU}$, the checkpoint-defective strains spourlated efficiently, generating good spore viability of at least $68 \%$. Over $60 \%$ of $\Delta \mathrm{radl} / \Delta \mathrm{rad} 1$ diploid cells underwent meiosis when $12 \mathrm{~mm}$ HU was added $2 \mathrm{hr}$ after the medium change (Fig. 1A, right), demonstrating that $\mathrm{rad}^{+}$is essential for the meiotic checkpoint. $\Delta c d s 1 /$ $\Delta c d s 1$ also underwent meiosis in the presence of HU, but $\Delta c h k 1 / \Delta c h k 1$ and $\Delta c r b 2 / \Delta c r b 2$ did not (Fig. 1B). $c h k 1^{+}$and $c d s 1^{+}$appear to have overlapping functions in the mitotic DNA replication checkpoint, yet during meiosis, the double mutant $\Delta c d s 1 / \Delta c d s 1 \Delta c h k 1 / \Delta c h k 1$ had no further defect in the DNA replication checkpoint than the single $\Delta c d s 1 / \Delta c d s 1$ mutant (Fig. 1B). In the presence of $\mathrm{HU}$, the checkpoint-defective strains attempted to form spores, but the spores produced were defective and only partially formed, as judged by cellular morphology and colony iodine staining. We conclude that there is a DNA replication checkpoint operative during meiosis, and that the genes $\mathrm{rad}^{+}$and $c d s 1^{+}$have a role in this checkpoint, whereas the DNA damage checkpoint genes $c h k 1^{+}$and $c r b 2^{+}$do not.

\section{Characterization of the meiotic DNA replication checkpoint genes}

The above experiments were carried out by shifting $h^{-} /$ $h^{+}$cells to $-\mathrm{N}$ medium, which results in a rather asynchronous entry into meiosis. To investigate the meiotic 
A
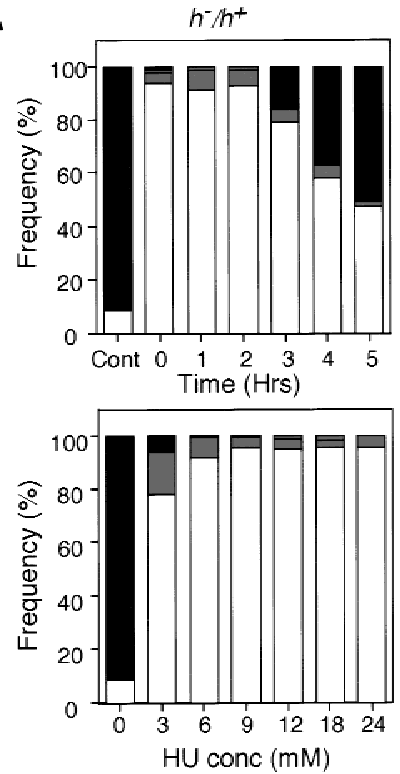

$\Delta \mathrm{rad} 1 / \mathrm{Arad} 1$
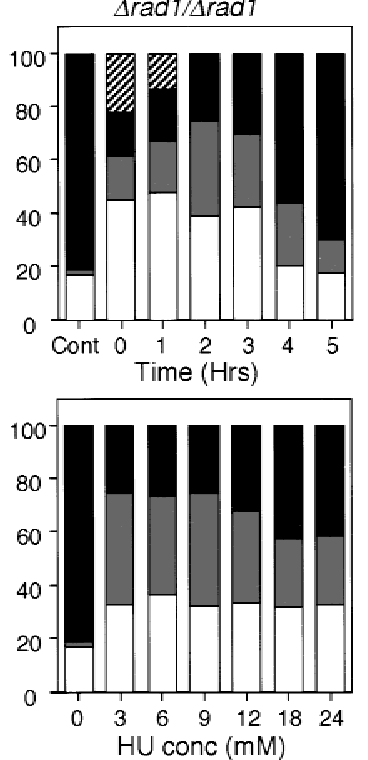

B

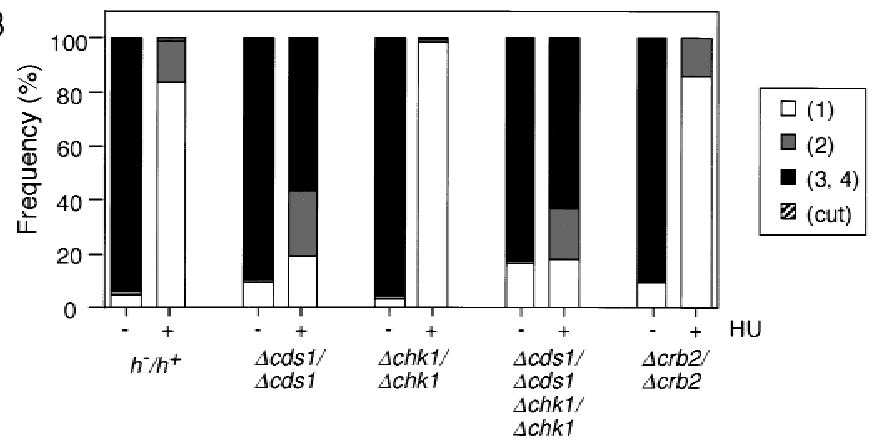

Figure 1. Rad1 and Cds1 are required for the meiotic DNA replication checkpoint. (A) $h^{-} / h^{+}$or $\Delta \mathrm{rad} 1 / \Delta \mathrm{rad} 1$ diploid cells heterozygous for the mating-type genes were grown to late log phase, washed, and transferred to $-\mathrm{N}$ medium at time 0. (Top) Sporulation was induced in the absence (Cont) or in the presence of $12 \mathrm{~mm} \mathrm{HU}$ added to the medium at the indicated times after the medium change. (Bottom) Sporulation was induced for $2 \mathrm{hr}$ and then the indicated concentrations of $\mathrm{HU}$ were added to the medium. Samples were collected after $17 \mathrm{hr}$ in the sporulation medium. The proportions of cells containing either one nucleus (white), two (gray), three or four nuclei (black), and the cut (hatched) cells were determined by fluorescence microscopy of DAPI-stained cells. The phenotype cut is the result of cells proceeding through mitosis when the DNA replication checkpoint is defective. $(B) \Delta c d s 1 / \Delta c d s 1$, $\Delta \operatorname{chk} 1 / \Delta \operatorname{chk} 1, \Delta c d s 1 / \Delta c d s 1 \Delta c h k 1 / \Delta c h k 1$, or $\Delta c r b 2 / \Delta c r b 2$ diploid cells were induced to sporulate at time 0 . HU (12 mM) was added to the culture $2 \mathrm{hr}$ after the medium change. The number of nuclei was counted and shown as in $A$.

DNA replication checkpoint further, we used a more synchronous meiotic system on the basis of shifting a pat $1^{\text {ts }}$ strain (temperature sensitive for the meiotic negative regulator Pat 1 ) to its restrictive temperature, $34^{\circ} \mathrm{C}$ (Iino and Yamamoto 1985; Nurse 1985; Bähler et al. 1991). This pat $1^{t s}$-induced meiosis is indistinguishable from normal meiosis (Y. Watanabe, pers. comm.). The diploid pat $1^{\text {ts }} /$ pat $^{\text {ts }}$ strain was grown to late log phase, transferred to $-\mathrm{N}$ medium that arrests cells in $\mathrm{G}_{1}$, and then shifted to the restrictive temperature $34^{\circ} \mathrm{C}$ to induce meiosis. More than $80 \%$ of pat $1^{\text {ts }} /$ pat $^{\text {ts }}$ cells failed to undergo nuclear division (Fig. 2A) when DNA replication was blocked by HU, as confirmed by FACS (Fig. 2B). In contrast, pat ${ }^{\text {ts }} /$ pat $^{\text {ts }} \Delta \mathrm{rad} 1 / \Delta \mathrm{rad} 1$ cells continued to undergo nuclear division after addition of $\mathrm{HU}$, although entry into meiosis I was delayed by $\sim 1 \mathrm{hr}$. Other checkpoint Rad genes, $\mathrm{rad3}^{+}$(see below), $\mathrm{rad}^{+}$, rad $17^{+}$, and hus $1^{+}$were also examined to determine whether they are involved in the meiotic DNA replication checkpoint. We found that mutants of all of these genes underwent meiotic nuclear division in the presence of HU with almost identical kinetics to those observed with the pat $1^{\text {ts }} /$ pat $^{\text {ts }} \Delta \mathrm{rad} 1 / \Delta \mathrm{rad} 1$ strain, indicating that they were defective in the meiotic DNA replication checkpoint.

pat $1^{\text {ts }} /$ pat $^{\text {ts }} \Delta c d s 1 / \Delta c d s 1$ cells also entered meiosis in the presence of $\mathrm{HU}$, with similar kinetics to the

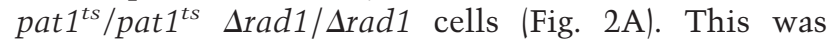
unexpected because entry into mitosis in the presence of $\mathrm{HU}$ is much delayed in mitotic $\Delta c d s 1$ cells (Murakami and Okayama 1995), suggesting that $c d s 1^{+}$ plays a more prominent role in the replication checkpoint during meiosis than it does during mitosis. Neither the pat1 ${ }^{\text {ts }} /$ pat1 $^{\text {ts }} \Delta$ chk $1 / \Delta$ chk1 nor the pat1 ${ }^{\text {ts }} /$ pat $^{\text {ts }}$ $\Delta c r b 2 / \Delta c r b 2$ cells entered meiosis when treated with $\mathrm{HU}$ (data not shown), confirming that neither $\operatorname{chk} 1^{+}$nor $\mathrm{crb2}^{+}$are involved in the meiotic DNA replication checkpoint.

Next, we studied the morphology of meiotic nuclei during these experiments (Fig. 3). It has been shown that at prophase the meiotic nucleus moves backward and forward in a manner described as horse-tail movements (Robinow 1977; Bähler et al. 1993; Chikashige et al. 1994). The horse-tail morphologies of the nuclei at this stage of meiosis in pat $1^{\text {ts }} /$ pat $1^{\text {ts }}$ cells were similar to those observed in normal diploid cells. When pat $1^{\text {ts }} /$ pat ${ }^{\text {ts }} \Delta \mathrm{rad} 1 / \Delta \mathrm{rad1}$, pat $1^{\text {ts }} /$ pat $^{\text {ts }} \Delta \mathrm{cds} 1 / \Delta \mathrm{cds} 1$, pat $1^{\text {ts }} /$

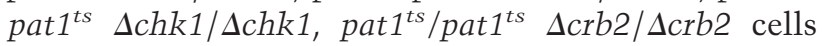
were induced to undergo meiosis, their nuclear morphologies were indistinguishable from pat $1^{t s} /$ pat $^{\text {ts }}$ cells (data not shown). When HU was added, pat $1^{t s} /$ pat $^{\text {ts }}$ cells arrested with nuclei exhibiting horse-tail mor-

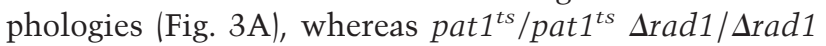
or pat $1^{\text {ts }} /$ pat $^{\text {ts }} \Delta c d s 1 / \Delta c d s 1$ cells underwent nuclear divisions although an uneven distribution of chromosomes was evident (Fig. 3B; data not shown). Like pat1 ${ }^{\text {ts }}$ / pat $1^{\text {ts }}$ cells, pat $1^{\text {ts }} /$ pat $1^{\text {ts }} \Delta$ chk $1 / \Delta$ chk1 or pat $1^{\text {ts }} /$ pat $^{1 \text { ts }}$ $\Delta c r b 2 / \Delta c r b 2$ cells arrested in prophase with nuclei having horse-tail morphology (data not shown).

During normal meiotic prophase, the cytoplasmic microtubules are organized exclusively from the spindle pole body (SPB) of a horse-tail nucleus (Chikashige et al. 1994; Hagan and Yanagida 1995; Svoboda et al. 1995; Hagan 1998), and during metaphase the SPBs separate and intranuclear spindles form as cytoplasmic microtubules disappear (Chikashige et al. 1994). Following an 
A
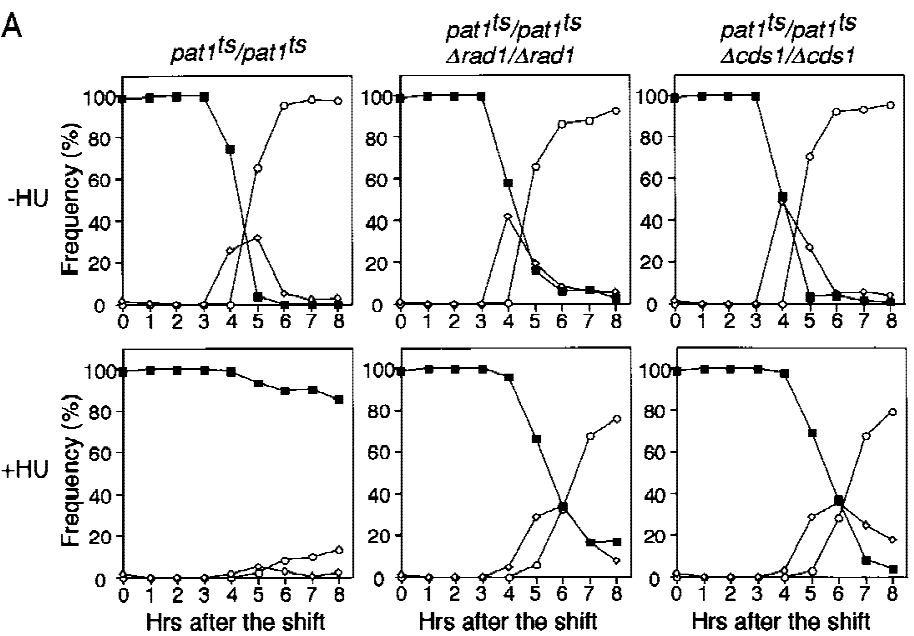

Figure 2. Radl and Cds1 are required for the meiotic DNA replication checkpoint in pat1-induced meiosis. (A) pat $1^{\text {ts }} /$ pat $^{\text {ts }}$, pat $1^{\text {ts }} /$ pat $^{\text {ts }}$ $\Delta \mathrm{rad1} / \Delta \mathrm{rad1}$, and $\mathrm{pat} 1^{\text {ts }} / \mathrm{pat}^{\text {ts }} \Delta c d s 1 / \Delta c d s 1$ diploid cells homozygous for the mating-type genes were grown to late log phase, washed, and transferred to $-\mathrm{N}$ medium for $14 \mathrm{hr}$ at $25^{\circ} \mathrm{C}$. The sporulation was induced by shifting the temperauture to $34^{\circ} \mathrm{C}$ at time 0 . Samples were taken after the temperature shift in the absence (top) or presence of $\mathrm{HU}$ (bottom). The proportions of the cells containing one nucleus ( $\mathbf{\square})$, two $(\diamond)$, and three or four nuclei $(O)$ were determined. These results were representative of five independent experiments. The maximum difference of the time when half of the cells has two or more nuclei was $30 \mathrm{~min}$ in these experiments. (B) DNA content of the cells over the time course of sporulation in the absence (top) or the presence of HU (bottom) was determined by FACS analysis.
B

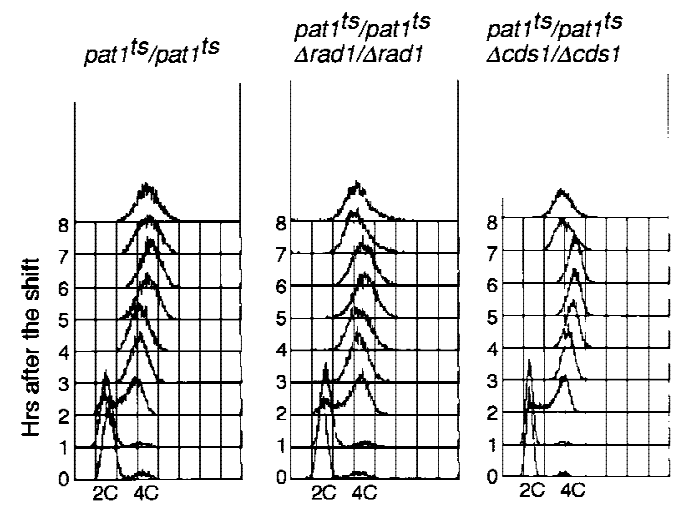

$+\mathrm{HU}$
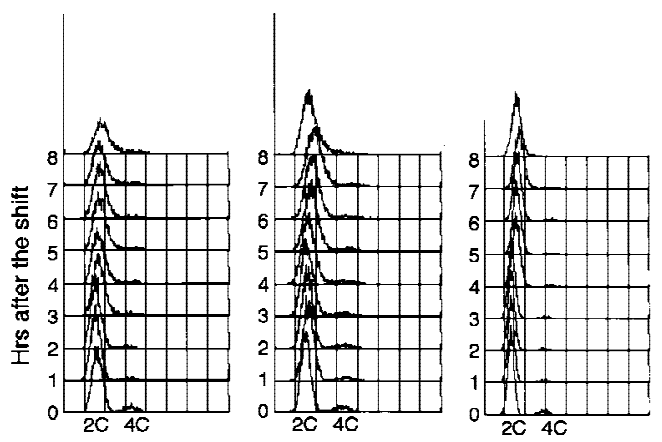

DNA content
HU block, $>70 \%$ of the cells showed a typical prophase configuration with most microtubules organized from a single SPB (Fig. 3A). We conclude that cells unable to complete premeiotic $S$ phase become arrested in prophase, although it is not clear whether the arrest point is in early or late prophase or whether linear elements have been formed or not. Linear elements function as a glue between sister chromatids and normally form concomitantly with the onset of premeiotic DNA replication (Bähler et al. 1993). In contrast, pat $1^{\text {ts }} / \mathrm{pat}^{\text {ts }} \mathrm{rad} 3 / \mathrm{rad} 3$ cells treated with HU undergo meiotic nuclear divisions, which, however, were defective (Fig. 3B). Intranuclear spindles were formed but were disorganized, SPBs were duplicated and separated, and the nucleus disintegrated into several fragments. The results indicate that pat $1^{\text {ts }} /$ pat $1^{\text {ts }} \mathrm{rad} 3 / \mathrm{rad} 3$ cells that have failed to complete premeiotic $S$ phase attempt to undergo meiotic nuclear divisions.

The meiotic DNA replication checkpoint inhibits Cdc2 kinase activity through Y15 phosphorylation

Cdc2 tyrosine 15 phosphorylation plays a key role in blocking onset of mitosis when DNA replication is incomplete. To check whether a similar biochemical mechanism is involved in the meiotic checkpoint, we monitored Cdc2 tyrosine phosphorylation and protein kinase activity in pat $1^{\text {ts }} /$ pat $1^{\text {ts }}$ cells undergoing meiosis and sporulation. The level of Cdc2 protein was almost constant during this experiment, both with and without HU (Fig. 4A). The level of the tyrosine-phosphorylated

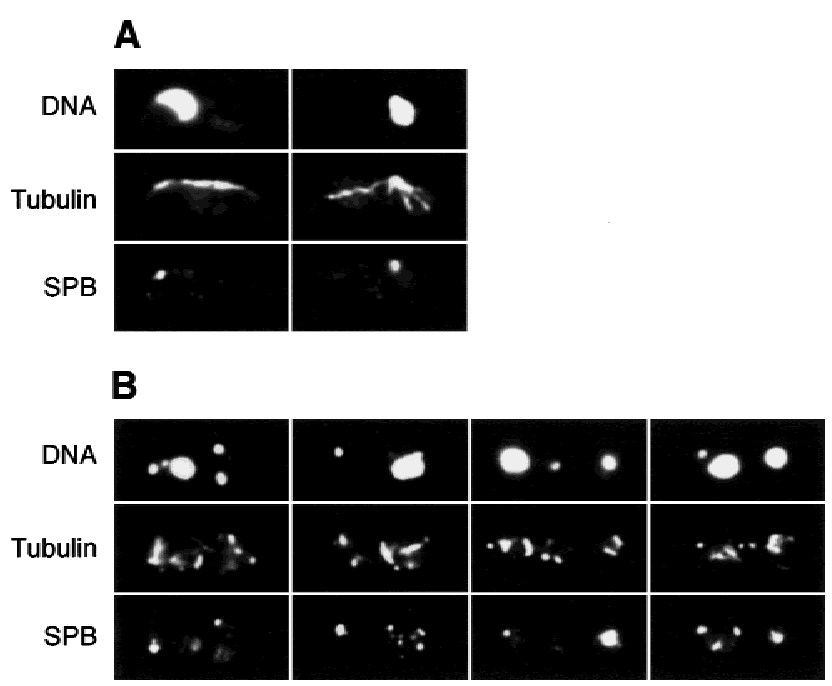

Figure 3. The meiotic DNA replication checkpoint arrests cells in prophase. The pat $1^{\text {ts }} /$ pat $^{\text {ts }}(A)$ and pat $1^{\text {ts }} /$ pat $^{\text {ts }}$ rad3/ rad3 cells $(B)$ were induced to undergo meiosis as in Fig. 2 for 6 $\mathrm{hr}$ at $34^{\circ} \mathrm{C}$ in $\mathrm{HU}$, processed for immunofluorescence and stained with anti-TAT1 and anti-Sad1 antibodies. Typical examples of images of a field of the cells are shown. (Top) Position and morphology of chromatin DNA stained with DAPI; (middle) anti-tubulin staining probed with anti-TAT1 antibody; (bottom) anti-Sad1 staining for a component of the SPB. 
form of Cdc2 gradually increased during premeiotic $S$ phase and decreased during meiotic division (Fig. 4A), but after $\mathrm{HU}$ was added, tyrosine 15 phosphorylation was maintained at a high level. Cdc13 B-cyclin protein gradually accumulated during $S$ phase, peaked around meiotic division, and then decreased, but after HU was added, the level of Cdc13 remained high. The high level of tyrosine 15 phosphorylation observed in HU suggests that Cdc2 protein kinase activity is inhibited when premeiotic $S$ phase is incomplete. To confirm this, we measured Cdc13- and Cdc2-dependent histone H1 kinase activity both with and without HU after immunoprecipitation with anti-Cdc13 and anti-Cde2 antibodies. The Cdc13-associated $\mathrm{H} 1$ kinase activity rose to a peak during the meiotic nuclear divisions (Fig. 4B), consistent with observations made with Sucl beads (Daya Makin et al. 1992). In contrast, cells in HU had a low Cdc13-associated kinase activity. Similarly, Cdc2 kinase activity peaked during meiotic nuclear division, whereas this activity remained low after addition of HU (Fig. 4B). These results indicate that the meiotic DNA replication checkpoint pathway inhibits Cdc2 kinase activity through Y15 phosphorylation.
Next, we examined the level of phosphorylation of Cdc2 tyrosine 15 in pat $1^{\text {ts }} /$ pat $^{\text {ts }}$ rad3/rad3 and pat $1^{\text {ts }} /$ pat $^{t s} \Delta c d s 1 / \Delta c d s 1$ cells with or without HU (Fig. 5A). Like pat $1^{\text {ts }} /$ pat $^{\text {ts }}$ cells, the tyrosine phosphorylation level of Cdc2 increased during premeiotic $S$ phase and decreased during meiotic division. When HU was added, tyrosine dephosphorylation still occurred, although it was delayed by $\sim 1 \mathrm{hr}$, as was the disappearance of Cdc 13. Thus, tyrosine 15 phosphorylation of Cdc2 cannot be maintained in meiotic cells lacking Rad3 or Cds1. Cdc13- and Cdc2-dependent kinase activities became elevated after the addition of HU to these cells, consistent with the observed tyrosine 15 dephosphorylation (Fig. 5B). The level of Cdc13 was a little higher and persists longer in $\mathrm{pat}^{\text {ts }} / \mathrm{pat}^{\text {ts }} \mathrm{rad} 3 / \mathrm{rad} 3$ cells, suggesting that they may have a slight defect in degrading Cdc13. The peak of kinase activity in pat $^{\text {ts }} /$ pat $^{\text {ts }} \mathrm{rad} 3 / \mathrm{rad} 3$ was lower in HU, probably because these cells entered meiosis less synchronously. Thus, when the DNA replication checkpoint control is defective, tyrosine 15 phosphorylation cannot be maintained and Cdc2 protein kinase activity increases. Because the checkpoint response is correlated with tyrosine 15 phosphorylation of Cdc2, we
A
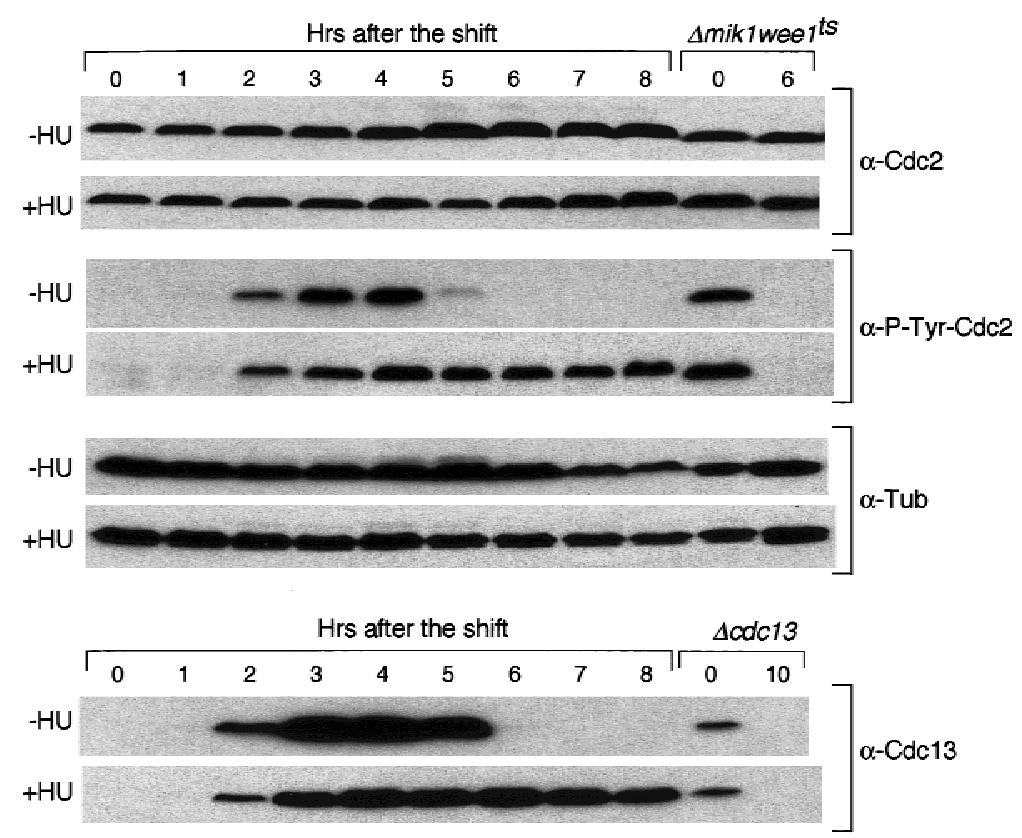

B
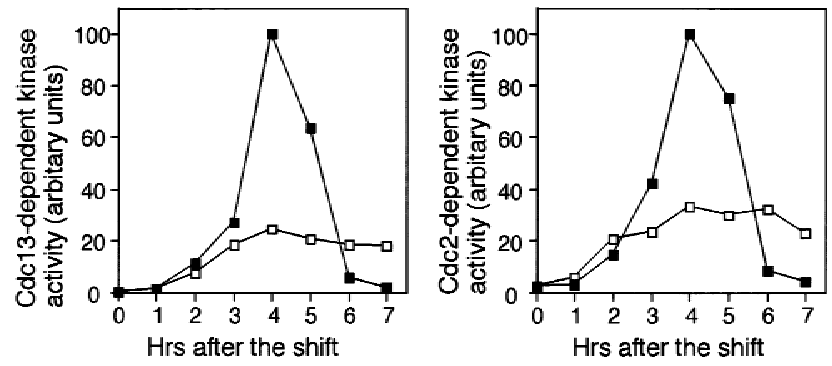

Figure 4. The meiotic DNA replication checkpoint inhibits Cdc2 kinase activity through Y15 phosphorylation. (A) Western blot analysis of the amount of tyrosine 15 phosphorylated $\mathrm{Cdc} 2$, and the abundance of $\mathrm{Cdc} 2$ and $\mathrm{Cdc} 13$ proteins. pat $1^{\text {ts }} /$ pat $^{\text {ts }}$ cells were induced to undergo meiosis as in Fig. 2. The samples were taken after the temperature shift at the indicated times in the absence $(-\mathrm{HU})$ or in the presence $(+\mathrm{HU})$ of HU. The levels of tyrosine 15 phosphorylated Cdc2 in the samples were monitored by Western blotting with an antibody specific to tyrosine 15 phosphorylated Cdc2 ( $\alpha$-P-Tyr-Cdc2). As a control for Y15 phosphorylated Cdc2, smik1 weel $^{t s}$ strain was grown to mid log phase, shifted to $36^{\circ} \mathrm{C}$ at time 0 and incubated for 6 $\mathrm{hr}$. The blots were reprobed with a monoclonal antibody specific to Cdc2 ( $\alpha$-Cdc2). As a loading control, the amount of $\alpha$-tubulin was analyzed $\alpha$-Tub). Similarly, the amount of Cdc13 was analyzed $(\alpha-\mathrm{Cdc} 13)$. As a control for Cdc13 protein, $\Delta c d c 13$ strain in which $c d c 13^{+}$expression is repressible by thiamine was grown in mid log phase. Thiamine was added to shut off the expression of $c d c 13^{+}$at time 0 and incubated for $10 \mathrm{hr}$. (B) pat ${ }^{\text {ts }} /$ pat $1^{\text {ts }}$ cells were grown and processed as above. Timing of entry into meiosis was delayed for $\sim 0.5 \mathrm{hr}$ compared with that in $\mathrm{A}$. Kinase activity associated with $\mathrm{Cdc} 13$ and Cdc2 was analyzed by immunoprecipitation with anti-Cdc13 and anti-Cdc2 antibodies from the samples in the absence ( $\square$ ) or presence ( $\square$ ) of HU. Immune complexes were washed, assayed for kinase activity with histone $\mathrm{H} 1$ as a substrate, and quantified by PhosphorImager analysis. 
Figure 5. Rad3 and Cds1 act upstream of $\mathrm{Cdc} 2$ in the meiotic DNA replication checkpoint $(A)$ pat $1^{\text {ts }} /$ pat $^{\text {ts }} \mathrm{rad} 3 / \mathrm{rad} 3$ and pat $1^{\text {ts }} /$ pat $^{\text {ts }} \Delta c d s 1 / \Delta c d s 1$ cells were induced to undergo meiosis in the absence $(-\mathrm{HU})$ or in the presence of $(+\mathrm{HU})$ of $\mathrm{HU}$ and processed as in Fig. 4. The amount of Cdc2 $(\alpha-\mathrm{Cdc} 2)$, the phosphorylation of Cdc2 tyrosine 15 ( $\alpha$-P-Tyr-Cdc2), and $\mathrm{Cdc} 13(\alpha-\mathrm{Cdc} 13)$ was analyzed by Western blotting as in Fig. 4. (B)pat $1^{\text {ts }} /$ pat $^{\text {ts }}$ rad3/ rad3 cells were grown and processed as above. Kinase activity associated with Cdc13 and Cdc2 from the samples in the absence ( $\square$ ) or presence ( $\square$ ) of HU was analyzed by immunoprecipitation with antiCdc13 and anti-Cdc2 antibodies and processed as in Fig. 4.
A
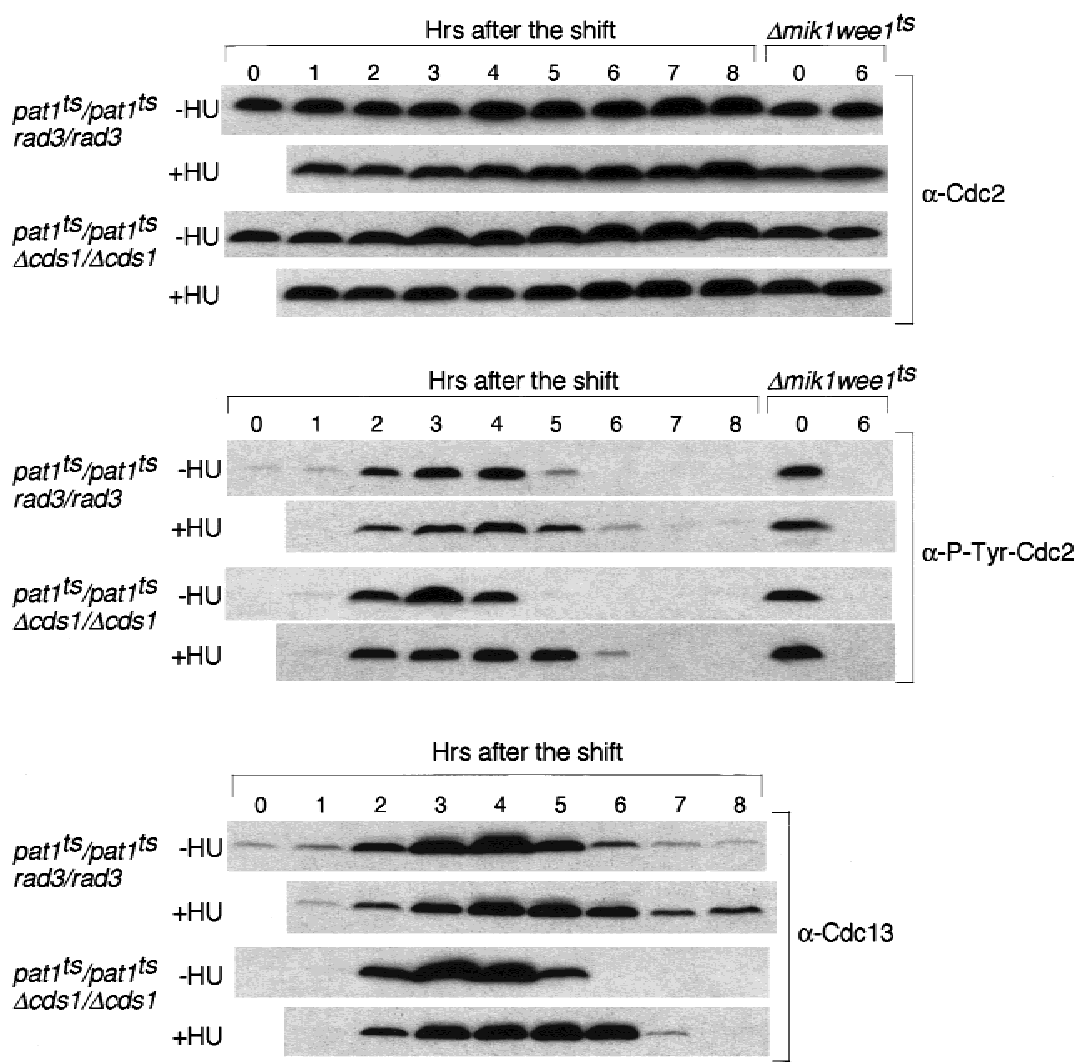

B
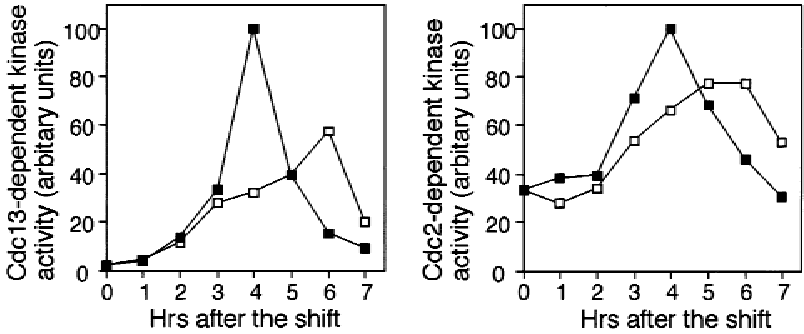

conclude that the checkpoint is mediated, at least in part, through this phosphorylation.

Tyrosine 15 dephosphorylation of Cdc2 is not sufficient to bring about nuclear division in an $\mathrm{HU}$ block

If the meiotic DNA replication checkpoint works through Cdc2 tyrosine 15 phosphorylation, then preventing this phosphorylation should allow meiotic nuclear divisions to proceed even during an HU block. Wee1 and Mik1 are the tyrosine kinases responsible for phosphorylating Cdc2 tyrosine 15 (Featherstone and Russell 1991; Lundgren et al 1991). We constructed a pat $1^{\text {ts }}$ strain in which mik $1^{+}$is deleted and wee $1^{+}$is temperature sensitive $\left(p a t 1^{\text {ts }} /\right.$ pat $1^{\text {ts }} \Delta$ mik $1 / \Delta$ mik1 wee $1^{\text {ts }} /$ wee $\left.1^{\text {ts }}\right)$. Growing cells were transferred to $-\mathrm{N}$ medium and shifted to $34^{\circ} \mathrm{C}$. They entered $\mathrm{S}$ phase with similar kinetics as the control pat1 $1^{\text {ts }} /$ pat $^{\text {ts }}$ strain (data not shown) but were advanced by $\sim 1$ hr into meiosis I (Fig. 6A). However, in contrast to mitotic cells treated with HU, nuclear divisions were blocked in meiotic cells treated with HU. Because a temperature of $34^{\circ} \mathrm{C}$ was used to induce efficient sporulation, it was possible that wee $1^{+}$was not fully inactivated at this temperature. However, $\Delta$ mik 1 wee $1^{\text {ts }}$ cells could proceed through mitosis in $\mathrm{HU}$ at $34^{\circ} \mathrm{C}$ (Fig. 6A). Even at $25^{\circ} \mathrm{C}$, the permissive temperature for wee $1^{\text {ts }}$, mitotic cells were unable to block nuclear division after addition of $\mathrm{HU}$ (data not shown), suggesting that wee $1^{+}$function is compromised enough even at $25^{\circ} \mathrm{C}$ to abrogate the mitotic checkpoint function when combined with $\Delta m i k 1$.

We constructed a diploid strain expressing Cdc2-Y15F or a pat $1^{\text {ts }}$ strain expressing Cdc2-Y15F. However, these strains failed to undergo meiosis even without HU. The reason for this failure of $\mathrm{Cdc}-2 \mathrm{Y} 15 \mathrm{~F}$ to undergo meiosis 
A

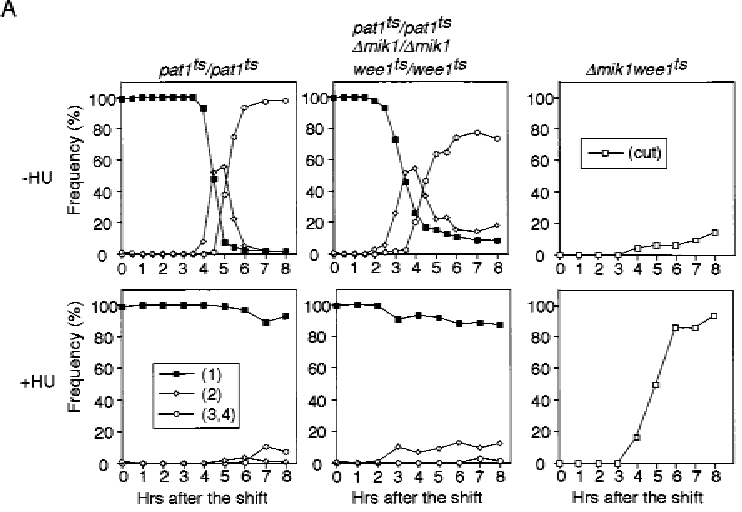

B

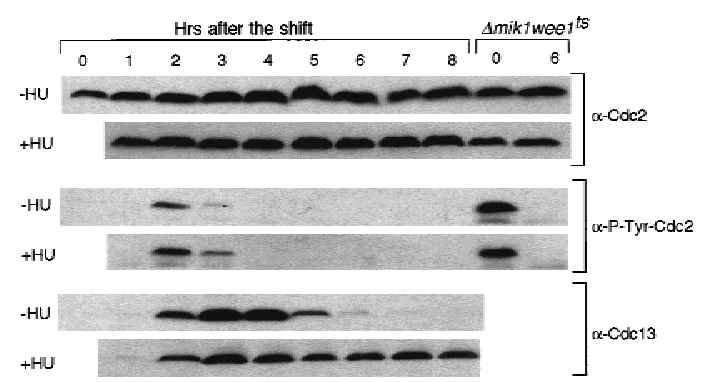

C

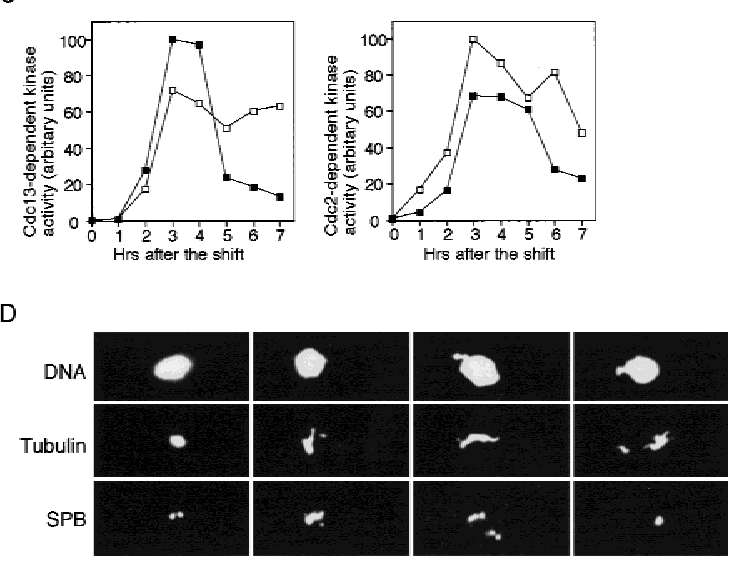

Figure 6. The meiotic DNA replication checkpoint arrests cells in metaphase-like stage with high Cdc2 kinase activity when Cdc2 tyrosine 15 in dephosphorylated. (A) pat $1^{\text {ts }} /$ pat1 $^{\text {ts }}$, pat $1^{\text {ts }} /$ pat $^{\text {ts }} \Delta$ mik1/ $\Delta$ mik1 wee $1^{\text {ts }} /$ wee $^{\text {ts }}$ diploid strains and $\Delta m i k 1$ wee $1^{\text {ts }}$ haploid strain were grown, washed, and transferred to $-\mathrm{N}$ medium at $25^{\circ} \mathrm{C}$. The cultures were then shifted to $34^{\circ} \mathrm{C}$ at time 0 . The samples were taken after the temperature shift at the indicated times in the absence (top) or in the presence (bottom) of HU. The proportions of the cells having one nucleus $(\mathbf{\square})$, two $(\diamond)$, and three or four neclei $(\bigcirc)$ for diploid strains and cut $(\square)$ for the haploid strain were determined. These results were representative of three independent experiments. The maximum difference of the time when one-half of the cells have two or more nuclei was $20 \mathrm{~min}$ in these experiments. $(B)$ The samples were taken after the temperature shift at the indicated times in the absence (-HU) or in the presence $(+\mathrm{HU})$ of HU. The amount of Cdc2 $(\alpha-\mathrm{Cdc} 2)$, the phosphorylation of Cdc2 tyrosine 15 ( $\alpha-\mathrm{P}-\mathrm{Tyr}-\mathrm{Cdc} 2)$, and Cdc13 $(\alpha-C d c 13)$ was analyzed by Western blotting as in Fig. $4 .(C)$ Kinase activity associated with Cdc13 and Cdc2 from the samples in the absence ( $\square$ ) or presence $(\square)$ of HU was analyzed by immunoprecipitation with anti-Cdc13 and anti-Cdc2 antibodies and processed as

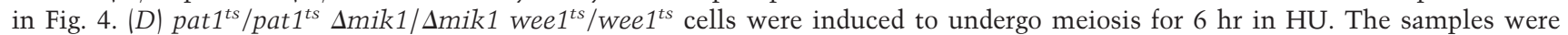
processed as in Fig. 3 and stained with anti-TAT1 and anti-Sad1 antibodies. Typical examples of images of a field of the cells are shown. (Top) Position and morphology of chromatin DNA stained with DAPI, (middle) anti-tubulin staining probed with anti-TAT1 antibody, (bottom) anti-Sad1 staining for a component of the SPB.

is not understood. We also constructed a pat $1^{\text {ts }}$ strain either with $c d c 2-3 w$, wee1, or mik1 mutation. These strains arrested before meiotic nuclear division in the presence of $\mathrm{HU}$, suggesting that either $c d c 2-3 w$, weel, or mik1 mutation is insufficient to override a checkpoint block by HU (data not shown).

We further explored the possibility that HU-induced arrest is dependent on the DNA damage checkpoint using a pat $1^{\text {ts }} \Delta$ mik1wee $1^{\text {ts }} \Delta c h k 1$ strain. Nuclear division was also blocked in this strain, suggesting that arrest is not dependent on the Chk1-dependent DNA damage checkpoint (data not shown). We next constructed a pat $1^{\text {ts }} \Delta$ mik1wee $1^{\text {ts }}$ rad3 strain to test whether these cells would undergo nuclear division in the presence of HU. This strain was induced to enter meiosis in the presence or absence of HU. In the absence of $\mathrm{HU}, 60 \%$ of the cells had entered meiosis within $8 \mathrm{hr}$ after the temperature shift, as shown by the presence of cells with two or more nuclei. This slow entry into meiosis is probably a consequence of the slow growth rate of this strain. In the presence of $\mathrm{HU}, 50 \%$ of the cells underwent an aberrant meiosis by this time point (data not shown). Similar results were obtained with a pat $1^{t s} \Delta$ mik1 wee $1^{\text {ts }} \Delta$ rad1 strain. These results clearly show that these strains by- pass the checkpoint arrest and undergo meiotic nuclear divisions in HU.

To test whether a third meiosis-specific tyrosine kinase might phosphorylate Cdc2 on tyrosine 15 , we monitored the level of Cdc2-phosphorylated tyrosine 15 in

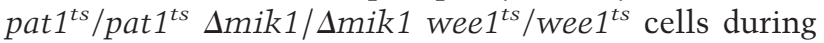
meiosis, both with and without HU (Fig. 6B). The Cdc2phosphorylated tyrosine 15 level transiently increased 2-3 hr after the shift, and then decreased. This was probably because $w e e 1^{+}$was not fully inactive at this temperature. However, tyrosine phosphorylation was completely absent within $4 \mathrm{hr}$ of the shift both in the presence and absence of HU. These results indicate that there is not a third meiosis-specific tyrosine kinase that phosphorylates Cdc2 tyrosine 15 and prevents meiotic nuclear divisions. These cells were also found to have high Cdc2- and Cdc13-associated protein kinase activity both in the presence and absence of HU (Fig. 6C). We conclude that when such cells are treated with HU, progression through meiosis is blocked by a mechanism that is independent of Cdc2 protein kinase inhibition.

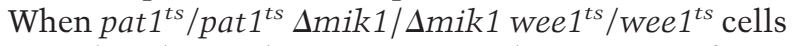
were induced to undergo meiosis in the presence of $\mathrm{HU}$, more than half of the cells showed short intranuclear 
spindles with a condensed nucleus and separated SPBs (Fig. 6D). In addition, a variety of spindle defects and cells with more than two SPBs were observed. These

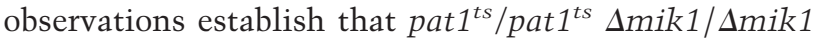
wee $1^{\text {ts }} /$ wee $1^{\text {ts }}$ cells treated with HU do not arrest in prophase, but arrest later during metaphase of meiosis I.

\section{Discussion}

Our investigations into the meiotic DNA replication checkpoint control in fission yeast have revealed the following. (1) A DNA replication checkpoint control operates that blocks onset of meiosis I when DNA replication is incomplete. (2) This checkpoint requires the Cds1, Rad1, 3, 9, 17, and Hus1 gene products. (3) When DNA replication is incomplete, the checkpoint maintains Cdc2 tyrosine 15 phosphorylation, and keeps Cdc2 protein kinase activity low. (4) A second checkpoint exists that blocks meiotic progression if the first checkpoint is inoperative. (5) This checkpoint blocks cells at metaphase of meiosis I with high Cdc2 protein kinase activity.

Meiotic nuclear division has been shown to be inhibited in fission yeast in response to inhibitors and mutations that block DNA replication (Grallert and Sipiczki 1991; Iino et al. 1995). We show here that this is a checkpoint-dependent process that requires all of the checkpoint genes identified previously as being necessary for the mitotic DNA replication checkpoint control. Additionally, the Cds1 kinase is absolutely required for the meiotic checkpoint. During the mitotic cell cycle, cells lacking Cds1 are initially delayed from entering mitosis when DNA replication is blocked by HU, although after some hours, mitosis does occur (Murakami and Okayama 1995). This contrasts with the situation in meiotic cells in which cells lacking Cds1 are completely checkpoint defective, undergoing meiosis I after a delay of only $1 \mathrm{hr}$ when DNA replication is incomplete. Unlike the checkpoint Rad products, Cds1 is not required in the mitotic DNA damage checkpoint, and it is possible that the delay in mitotic onset seen in $\Delta c d s 1$ cells may be a consequence of HU-induced DNA damage, which activates the DNA damage checkpoint and blocks mitosis. This mitotic checkpoint can operate independently of Cds1 but is dependent on the checkpoint Rad gene products. The different situation seen during meiosis may be because HU does not induce DNA damage, or because the damage induced may be more effectively repaired and so the DNA damage checkpoint is not invoked. As a consequence, $\Delta c d s 1$ cells can proceed into meiosis I with the same kinetics as $\Delta \mathrm{rad} 1$ cells. If this interpretation is correct, then Cds1 may be specifically involved in monitoring incomplete or stalled DNA replication in both mitotic and meiotic cells. Alternatively, Cds1 may act redundantly with Chk1 during the mitotic cell cycle (Boddy et al. 1998; Lindsay et al. 19987; Zeng et al. 1998), with Chk1 function suppressed during the meiotic cell cycle, explaining why $\Delta c d s 1$ cells are completely defective in activating the meiotic DNA replication checkpoint.
The checkpoint Rad proteins and Cds1 act upstream of Cdc2 in the meiotic DNA replication checkpoint. When DNA replication is blocked with $\mathrm{HU}, \mathrm{Cdc} 2$ and the Bcyclin Cdc13 persist and phosphorylation of Cdc2 tyrosine 15 is maintained. Cdc2 protein kinase activity is kept at a low level because of this phosphorylation and the onset of meiosis I is blocked. Similar behavior of Cdc2 is observed when DNA replication is blocked in mitotic cells (Rhind and Russell 1998b). In checkpointdeficient cells lacking the checkpoint Rad gene functions, Cdc2 tyrosine 15 phosphorylation is not maintained and Cdc2 protein kinase rises resulting in an abortive meiosis I and II.

Unexpectedly, blocking DNA replication with HU in cells that lack tyrosine 15 phosphorylated Cdc2 did not result in cells undergoing abortive nuclear divisions. This experiment was carried out with a pat $1^{\text {ts }} /$ pat $^{\text {ts }}$ $\Delta$ mik1/Dmik1 wee $1^{\text {ts }} /$ wee $1^{\text {ts }}$ mutant that lacks the known Cdc2 tyrosine 15 protein kinases, resulting in undetectable levels of tyrosine phosphorylation and high levels of Cdc2 protein kinase at the time of arrest. Despite high levels of the kinase, the cells do not proceed through abortive nuclear divisions, but arrest around metaphase of meiosis I with a short spindle extending between separated SPBs within an undivided nucleus. The fact that in the absence of the checkpoint Rad genes such cells proceeded into abortive nuclear divisions suggests that the checkpoint control must have two downstream pathways that can potentially block meiotic progression (Fig. 7). The first operates through Cdc2 tyrosine 15 phosphorylation, which is similar to the mitotic DNA replication checkpoint, whereas the second, which is specific for meiosis, must operate through an alternative mechanism downstream of Cdc2 activation.

This result leads to two questions: What is the molecular basis of this second mechanism and why should this be operative only in meiotic cells? There have been several reports of two independent mechanisms being involved in mitotic DNA replication checkpoint controls. In Aspergillus nidulans, cells containing nontyrosine-phosphorylated Cdc2 still arrest before mitosis with high Cdc2 protein kinase activity (Ye et al. 1996). However, at this arrest point no spindle has formed, a block at an earlier stage than that observed with the second mechanism operating during fission yeast meiosis. A BimE mutation, defective in an APC subunit in A. nidulans, can overcome this block (Ye et al. 1996). In both Xenopus egg extracts and human cells, tyrosine phosphorylation of Cdc2 is an important but not the sole mechanism operating in the mitotic DNA replication checkpoint (Kumagai and Dunphy 1995; Jin et al. 1996; Blasina et al. 1997). In budding yeast, tyrosine phosphorylation of the Cdc2 homolog Cdc28 does not operate in the mitotic DNA replication checkpoint control, and cells arrest with high $\mathrm{Cdc} 28$ protein kinase activity, short microtubule spindles, and separated SPBs (Amon et al. 1992; Sorger and Murray 1992; Stueland et al. 1993). The molecular mechanism underlying this checkpoint is not known (Weinert 1998a,b). These reports suggest that there are likely to be at least two mechanisms that can 


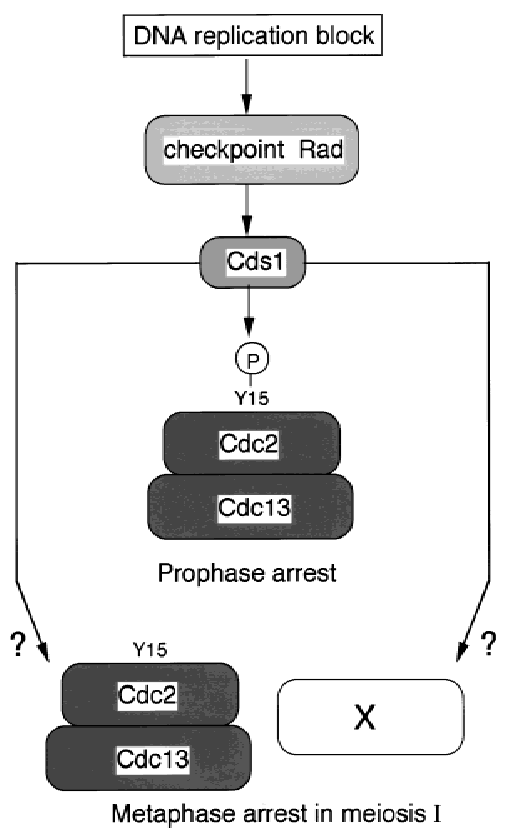

Figure 7. A model for the meiotic DNA replication checkpoint control. The signal of DNA replication block is sensed by the checkpoint Rad proteins and is transmitted to Cds1. The signal from Cds1 is branched in two ways; one is to maintain the tyrosine 15 phosphorylation of Cdc2 in prophase and another is to act on an unknown factor $(\mathrm{x})$ or to stabilize Cdc2 activity in metaphase.

block completion of mitosis when DNA replication is incomplete, one of which involves Cdc2 tyrosine phosphorylation. During mitosis in fission yeast, only the Cdc2 tyrosine phosphorylation mechanism is operative, but in meiosis, a second mechanism also comes into play, which could be equivalent to the budding yeast mitotic checkpoint control because the block is at a similar stage with a short spindle and separated SPBs. The molecular target of this second mechanism is not known, but two possibilities can be envisaged (Fig. 7). The control might operate through regulation of APC activity, preventing the fall in Cdc2-Cdc13 kinase activity and, as a consequence, blocking further meiotic progression (Hwang et al. 1998), or could regulate an unknown factor $\mathrm{X}$ required at a late stage of meiosis I (Fig. 7).

The second question is why should there be an extra checkpoint control that operates during meiosis in fission yeast but not during mitosis? Discussion of this question centers on the differences between the meiotic and mitotic cell cycles (Roeder 1997). One difference is that the levels of recombination are much higher. Possibly, a second checkpoint control exists to monitor whether recombination is complete and blocking DNA replication mimics in some way the production of recombination intermediates and so additionally activates this checkpoint. A recombination checkpoint has been proposed for budding yeast meiosis (Lydall et al. 1996). Another difference may be that meiosis I takes longer to complete than mitosis, and there needs to be a second late checkpoint that can come into play if there is DNA damage after activation of the Cdc2 protein kinase and the onset of meiosis. If a block in DNA replication with HU either generates DNA damage or mimics the structures produced by DNA damage, then this late checkpoint may come into play after Cdc2 protein kinase activation and would arrest cells with a short spindle. A third difference between meiosis and mitosis is that the chromosome arrangements are not identical (Scherthan et al. 1994; Roeder 1997). During meiosis there is chromosome homolog pairing that does not occur during mitosis. A checkpoint control blocking meiotic progression may need to operate that detects whether chromosome homolog pairing has not been completed (Rockmill and Roeder 1998). If DNA replication is incomplete, there cannot be correct homolog pairing and so this checkpoint may be activated. Given that the cells arrest with high Cdc2 protein kinase activity, such a checkpoint must operate after $\mathrm{Cdc} 2$ protein kinase activation and may overlap with spindle checkpoint controls.

This work has shown that there is a Cdc2 tyrosine 15 phosphorylation DNA replication checkpoint controlling Cdc2 protein kinase activation, which operates during fission yeast meiosis. This is the first demonstration of the molecular level of a DNA replication checkpoint control during meiosis. In addition, there is a second checkpoint control that does not operate during mitosis (Fig. 7). The molecular mechanism underlying this control is not understood, but it must respond to a situation that only operates during meiosis, such as differences in recombination, the duration of meiotic nuclear division, or chromosomal homolog pairing. It will be important to establish whether similar controls operate during meiosis in multicellular eukaryotes. Although several genes such as ATR, ATM, and Chk1 have been suggested as being involved in the meiotic checkpoint in mouse and human cells (Keegan et al. 1996; Xu et al. 1996; Flaggs et al. 1997; Barlow et al. 1998), the mechanism remains quite uncharacterized. Work in the fission yeast on this control should help direct similar studies in these more complex cells.

\section{Materials and methods}

Fission yeast strains and methods

All strains used were constructed by standard procedures (Moreno et al. 1991) and are shown in Table 1; pat $1^{\text {ts }} /$ pat $^{\text {ts }}$ cells used in Figure 2 were strain 2158 and in Figures 3, 4, and 6 were strain 2159 . The diploid strains homozygous for the mating-type genes were constructed by cell fusion. Complete medium (YES) and minimal medium (EMM) were described previously (Moreno et al. 1991).

To obtain meiotic cultures for the diploid strains heterozygous for the mating-type genes, single colonies were grown in YES to stationary phase. The cells were diluted in EMM supplemented with $100 \mu \mathrm{g} / \mathrm{ml}$ leucine and grown at $30^{\circ} \mathrm{C}$ with shaking to $1-1.5 \times 10^{7}$ cells $/ \mathrm{ml}$. For nitrogen starvation experiments, the cultures were filtrated through a Millipore membrane, washed with $-\mathrm{N}$ medium and resuspended in $-\mathrm{N}$ medium con- 
Table 1. S. pombe strains used in this study

\begin{tabular}{|c|c|}
\hline 827 & $h^{-}$mik1::LEU2 wee1-50 leu1-32 (Dmik1 wee $\left.1^{\text {ts }}\right)$ \\
\hline 1312 & $h^{-}$cdc13::ura4 int REP41::cdc13 ura4-D18 leu1-32 ade6 (Acdc13) \\
\hline 2158 & $h^{-} / h^{-}$pat1-114/pat1-114 leu1-32/leu1-32 ade6-M210/ade6-M216 (pat1 ${ }^{\text {ts }} /$ pat1 $^{\text {ts }}$ ) \\
\hline 2159 & $h^{+} / h^{+}$pat1-114/pat1-114 ade6-M210/ade6-M216 (pat1 ${ }^{t s} /$ pat $\left.^{t s}\right)$ \\
\hline 2160 & $\mathrm{~h}^{-} / \mathrm{h}^{-}$pat1-114/pat1-114 $\mathrm{rad3}-136 / \mathrm{rad3}-136$ ade6-M210/ade6-M216 $\left(\mathrm{pat1}^{\text {ts }} / \mathrm{pat}^{\text {ts }} \mathrm{rad} 3 / \mathrm{rad} 3\right)$ \\
\hline 2161 & 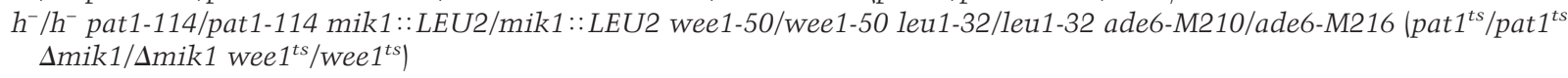 \\
\hline 2194 & 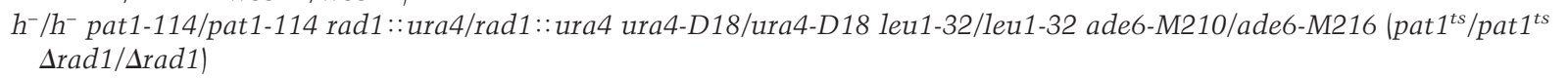 \\
\hline 2195 & 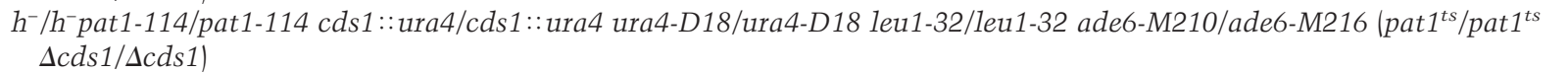 \\
\hline 2304 & $h^{-} / h^{+}$leu1-32/leu1-32 ade6-M210/ade6-M216 $\left(h^{-} / h^{+}\right)$ \\
\hline 2305 & 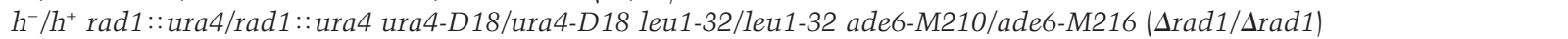 \\
\hline 2306 & 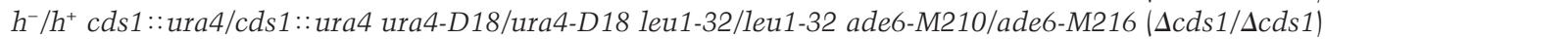 \\
\hline 2307 & 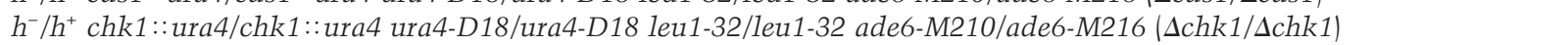 \\
\hline 2332 & 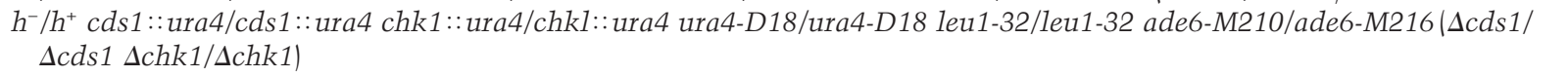 \\
\hline 2334 & 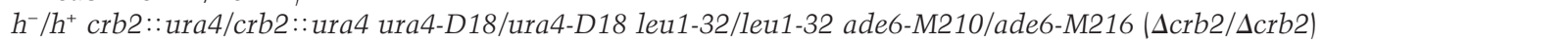 \\
\hline 2337 & $\begin{array}{l}h^{-} / h^{-} \text {pat1-114/pat1-114 cds1::ura4/cds1::ura4 ura4-D18/ura4-D18 leu1-32/leu1-32 ade6-M210/ade6-M216 (pat1 }{ }^{\text {ts }} / \text { pat }^{\text {ts }} \\
\quad \Delta c d s 1 / \Delta c d s 1)\end{array}$ \\
\hline 2338 & 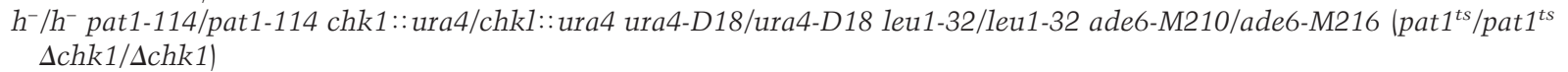 \\
\hline 2339 & 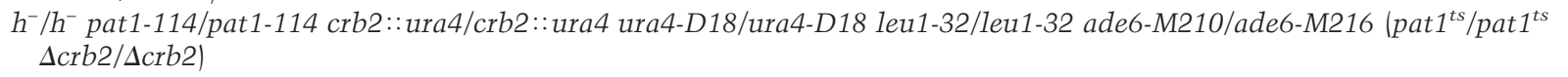 \\
\hline
\end{tabular}

Strains 827 and 1312 were from our laboratory stock and the others were constructed in this study.

taining $50 \mu \mathrm{g} / \mathrm{ml}$ leucine and $0.5 \%$ glucose. Sporulation was induced by vigorous shaking $(200 \mathrm{rpm})$ at $30^{\circ} \mathrm{C}$.

For the diploid strains homozygous for the mating-type genes, single colonies were grown in YES to stationary phase. The cells were diluted in EMM supplemented with $100 \mu \mathrm{g} / \mathrm{ml}$ leucine and grown at $25^{\circ} \mathrm{C}$ with shaking to $1-2 \times 10^{7}$ cells $/ \mathrm{ml}$. The cultures were filtrated through a Millipore membrane, washed with $-\mathrm{N}$ medium and resuspended in $-\mathrm{N}$ medium containing 50 $\mu \mathrm{g} / \mathrm{ml}$ leucine. The concentrations of the cells were adjusted to $4 \times 10^{6}$ to $6 \times 10^{6} / \mathrm{ml}$ and incubated at $25^{\circ} \mathrm{C}$ for $13-15 \mathrm{hr}$. $\mathrm{NH}_{4} \mathrm{Cl}$ and leucine were added to the cultures at $500 \mu \mathrm{g} / \mathrm{ml}$ and $50 \mu \mathrm{g} /$ $\mathrm{ml}$, respectively, just before the cultures were shifted to $34^{\circ} \mathrm{C}$ in the presence or absence of $24 \mathrm{~mm} \mathrm{HU}$.

\section{DAPI staining}

For staining of the cells with DAPI, $1 \mathrm{ml}$ of cell culture (1$2 \times 10^{7}$ cells) was centrifuged briefly, fixed with $70 \%$ ethanol and stored. Fifty microliters of fixed cells $\left(\sim 5 \times 10^{5}\right.$ cells $)$ were then added to $1 \mathrm{ml}$ of water, centrifuged, and resuspended with $100 \mu \mathrm{l}$ of water. A total of $7 \mu \mathrm{l}$ was spotted onto slides and dried by heating. The number of nuclei was counted under microscopy with DAPI solutions $(5 \mu \mathrm{g} / \mathrm{ml})$. At each time point, $>200$ cells were counted.

\section{Criteria for meiotic progression}

In meiosis, cells undergo DNA replication, separation of SPBs, and spindle formation, followed by two successive nuclear divisions. In this study, we have used both the number of nuclei by DAPI staining and formation of a spindle by immunostaining as criteria for progression into meiosis.

\section{Flow cytometric analysis}

A total of $5 \times 10^{5}$ cells were fixed in $70 \%$ ethanol, washed in 1 $\mathrm{ml}$ of $10 \mathrm{~mm}$ EDTA (pH 8.0), resuspended in $1 \mathrm{ml}$ of $10 \mathrm{~mm}$
EDTA solution containing $0.05 \mathrm{mg} / \mathrm{ml}$ of RNase A and incubated overnight at $37^{\circ} \mathrm{C}$. A total of $2 \mu \mathrm{g} / \mathrm{ml}$ propidium iodide was added to the solution and sonicated. We then followed the previously published protocol for flow cytometry (Sazer and Sherwood 1990), with a Becton-Dickinson FACScan.

\section{Antibodies}

The following antibodies were used: phospho-Cdc2 (Tyr15) polyclonal rabbit antibodies (New England Biolabs); Cdc2 monoclonal antibodies y63MAb (ICRF); rabbit polyclonal Cdc2 antibodies $\mathrm{C} 2$ (this laboratory); Cdc13 monoclonal antibodies 6F11/2 MAb (this laboratory); rabbit polyclonal Cdc13 antibodies SP4 (this laboratory); TAT1 monoclonal antibodies [gift of K. Gull (Woods et al. 1989)]; Sad1 polyclonal rabbit antibodies [gift of I. Hagan (Hagan and Yanagida 1995)]; anti- $\alpha$-tubulin monoclonal antibody (Sigma T5168).

\section{Protein preparation and Western blotting}

Total boiled protein extracts were prepared from $1-4 \times 10^{8}$ cells harvested by centrifugation, washed in STOP buffer $(150 \mathrm{~mm}$ $\mathrm{NaCl}, 50 \mathrm{~mm} \mathrm{NaF}, 10 \mathrm{~mm}$ EDTA, $1 \mathrm{~mm} \mathrm{NaN}_{3}$ at $\mathrm{pH} 8.0$ ) and resuspended in $100 \mu \mathrm{l}$ of $\mathrm{HB}$ buffer as described previously (Moreno et al. 1991; Yamaguchi et al. 1997). Cells were boiled for $5 \mathrm{~min}$ and broken with glass beads. After the cell breakage, the crude extracts were recovered by washing the glass beads with $200 \mu \mathrm{l}$ of $\mathrm{HB}$ buffer. The protein concentrations of the samples were determined by the BCA assay kit (Sigma). Cell extracts were reboiled in $4 \times$ sample buffer $(200 \mathrm{~mm}$ Tris-Cl at pH6.8, 0.4 M DTT, $8 \%$ SDS, $0.4 \%$ BPB, $40 \%$ glycerol). A total of $40 \mu \mathrm{g}$ protein from each sample was run on a $12 \%$ SDS-polyacrylamide gel. For Western blots, the protein was blotted to Immobilon-P membrane (Millipore) and detected by ECL (Amersham). Dilutions of the antibodies were 1:750 for anti-phospho-Cdc2 (Tyr15), 1:3000 for anti-Cdc2 mAb, 1:750 for anti-Cdc $13 \mathrm{mAb}$, and 1:50000 for anti- $\alpha$-tubulin $\mathrm{mAb}$. 


\section{Immunoprecipitation and kinase assays}

Extracts were prepared from frozen cells with glass beads in $\mathrm{HB}$ buffer previously (Moreno et al 1991). Soluble extracts were obtained by centrifugation at $13,000 \mathrm{rpm}$ for $10 \mathrm{~min}$ at $4^{\circ} \mathrm{C}$. Then, $2 \mu \mathrm{l}$ of rabbit polyclonal Cdc2 antibody C2 or $5 \mu \mathrm{l}$ of rabbit polyclonal Cdc 13 antibody SP4 were added to $500 \mu \mathrm{g}$ of protein and incubated for $45 \mathrm{~min}$ on ice. Pre-equilibrated protein A-Sepharose beads (Pharmacia Biotech) were added and the mixture agitated for $30 \mathrm{~min}$ at $4^{\circ} \mathrm{C}$. Beads were washed three times and then resuspended in $20 \mu \mathrm{l}$ of reaction buffer, containing $1 \mathrm{mg} / \mathrm{ml}$ histone $\mathrm{H1}$ (Calbiochem), $200 \mathrm{~mm}$ ATP and 40 $\mu \mathrm{Ci} / \mathrm{ml}\left[\gamma_{-}{ }^{32} \mathrm{P}\right]$ ATP (Amersham). Extracts were incubated at $30^{\circ} \mathrm{C}$ for $20 \mathrm{~min}$, stopped by boiling for $5 \mathrm{~min}$ after the addition of $4 \times$ SDS sample buffer and run on a $12 \%$ SDS-polyacrylamide gel. Phosphorylated histone H1 was detected by autoradiography and quantitated with a PhosphorImager.

\section{Immunofluorescence}

For immunofluorescence, cells were harvested, washed with $\mathrm{H}_{2} \mathrm{O}$, and fixed with methanol at $-20^{\circ} \mathrm{C}$. Cells were further processed for immunofluorescence as described (Sawin and Nurse 1998). Dilutions of the antibodies were 1:15 for TAT1 monoclonal anti-tubulin antibody and 1:25 for anti-Sad1 antibody, which recognizes a component of the SPB. Color images were produced by image capture with a Hamamatsu SIT Camera and C2400 processor for capturing the information. All images were subsequently processed with Adobe Photoshop.

\section{Acknowledgments}

We are grateful to Mitsuhiro Yanagida for strains and to Keith Gull and Iain Hagan for antibodies. We thank Yoshinori Watanabe and Jürg Bähler for introductions to meiosis and helpful discussions. We thank Chris Lehane, Dominic Griffiths, Gerald Smith, Jacky Hayles, José Ayté, Jürg Bähler, Satoko Yamaguchi, and Takashi Toda for critical reading of the manuscript. We also thank Jacky Hayles and Damian Brunner for assistance with kinase assays and immunofluorescence. We thank all members of the Nurse laboratory for their help. H.M. was supported by JSPS.

The publication costs of this article were defrayed in part by payment of page charges. This article must therefore be hereby marked 'advertisement' in accordance with 18 USC section 1734 solely to indicate this fact.

\section{References}

Al-Khodairy, F. and A.M. Carr. 1992. DNA repair mutants defining G2 checkpoint pathways in Schizosaccharomyces pombe. EMBO J. 11: 1343-1350.

Al-Khodairy, F., E. Fotou, K.S. Sheldrick, D.J.F. Griffiths, A.R. Lehman, and A.M. Carr. 1994. Identification and characterisation of new elements involved in checkpoint and feedback controls in fission yeast. Mol. Biol. Cell. 5: 147-160.

Amon, A., U. Surana, I. Muroff, and K. Nasmyth. 1992. Regulation of p34 ${ }^{C D C 28}$ tyrosine phosphorylation is not required for entry into mitosis in S. cerevisiae. Nature 355: 368-371.

Bähler, J., P. Schuchert, C. Grimm, and J. Kohli. 1991. Synchronized meiosis and recombination in fission yeast: Observations with pat1-114 diploid cells. Curr. Genet. 19: 445-451.

Bähler, J., T. Wyler, J. Loidl, and J. Kohli. 1993. Unusual nuclear structures in meiotic prophase of fission yeast: A cytological analysis. J. Cell. Biol. 121: 241-256.
Barlow, C., M. Liyanage, P.B. Moens, M. Tarsounas, K. Nagashima, K. Brown, S. Rottinghaus, S.P. Jackson, D. Tagle, T. Ried, and A. Wynshaw-Boris. 1998. Atm deficiency results in severe meiotic disruption as early as leptonema of prophase I. Development. 125: 4007-4017.

Blasina, A., E.S. Paegle, and C.H. McGowan. 1997. The role of inhibitory phosphorylation of CDC2 following DNA replication block and radiation-induced damage in human cells. Mol. Biol. Cell. 8: 1013-1023.

Blasina, A., I.V. de Weyer, M.C. Laus, W. Luyten, A.E. Parker, and C.H. McGowan. 1999. A human homologue of the checkpoint kinase Cds1 directly inhibits Cdc25 phosphatase. Curr. Biol. 9: 1-10.

Boddy, M.N., B. Furnari, O. Mondesert, and P. Russell. 1998. Replication checkpoint enforced by kinases Cds1 and Chk1. Science 280: 909-912.

Chikashige, Y., D.Q. Ding, H. Funabiki, T. Haraguchi, S. Mashiko, M. Yanagida, and Y. Hiraoka. 1994. Telomere-led premeiotic chromosome movement in fission yeast. Science 264: 270-273.

Daya Makin, M., P. Szankasi, L. Tang, D. MacRae, and S.L. Pelech. 1992. Regulation of $\mathrm{p} 105^{\text {wee } 1}$ and $\mathrm{p} 34^{\text {cdc2 }}$ during meiosis in Schizosaccharomyces pombe. Biochem. Cell. Biol. 70: 1088-1096.

Enoch, T. and P. Nurse. 1990. Mutation of fission yeast cell cycle control genes abolishes dependence of mitosis on DNA replication. Cell 60: 665-673.

Enoch, T., K. Gould, and P. Nurse. 1991. Mitotic checkpoint control in fission yeast. Cold Spri. Harb. Symp. Quant. Biol. 56: 409-416.

Enoch, T., A. Carr, and P. Nurse. 1992. Fission yeast genes involved in coupling mitosis to completion of DNA replication. Genes \& Dev. 6: 2035-2046.

Featherstone, C. and P. Russell. 1991. Fission yeast p107wee1 mitotic inhibitor is a tyrosine/serine kinase. Nature 349: 808-811.

Flaggs, G., A.W. Plug, K.M. Dunks, K.E. Mundt, J.C. Ford, M.R. Quiggle, E.M. Taylor, C.H. Westphal, T. Ashley, M.F. Hoekstra, and A.M. Carr. 1997. Atm-dependent interactions of a mammalian chk1 homolog with meiotic chromosomes. Curr. Biol. 7: 977-986.

Fogarty, P., S.D. Campbell, R. Abu-Shumays, B.S. Phalle, K.R. Yu, G.L. Uy, M.L. Goldberg, and W. Sullivan. 1997. The Drosophila grapes gene is related to checkpoint gene chk1/ rad27 and is required for late syncytial division fidelity. Curr. Biol. 7: 418-426.

Freire, R., J.R. Murguia, M. Tarsounas, N.F. Lowndes, P.B. Moens, and S.P. Jackson. 1998. Human and mouse homologs of Schizosaccharomyces pombe rad1(+) and Saccharomyces cerevisiae RAD17: Linkage to checkpoint control and mammalian meiosis. Genes \& Dev. 12: 2560-2573.

Furnari, B., N. Rhind, and P. Russell. 1997. Cdc25 mitotic inducer targeted by chk1 DNA damage checkpoint kinase. Science 277: 1495-1497.

Grallert, B. and M. Sipiczki. 1991. Common genes and pathways in the regulation of the mitotic and meiotic cell cycles of Schizosaccharomyces pombe. Curr. Genet. 20: 199-204.

Hagan, I.M. 1998. The fission yeast microtubule cytoskeleton. J. Cell. Sci. 111: 1603-1612.

Hagan, I. and M. Yanagida. 1995. The product of the spindle formation gene sad1 $^{+}$associates with the fission yeast spindle pole body and is essential for viability. J. Cell. Biol. 129: 1033-1047.

Hari, K.L., A. Santerre, J.J. Sekelsky, K.S. McKim, J.B. Boyd, and R.S. Hawley. 1995. The mei-41 gene of D. melanogaster is a structural and functional homolog of the human ataxia tel- 
angiectasia gene. Cell 82: 815-821.

Hartwell, L. and T. Weinert. 1989. Checkpoints: Controls that ensure the order of cell cycle events. Science 246: 629-634.

Hwang, L.H., L.F. Lau, D.L. Smith, C.A. Mistrot, K.G. Hardwick, E.S. Hwang, A. Amon, and A.W. Murray. 1998. Budding yeast Cdc20: A target of the spindle checkpoint. Science 279: $1041-1044$.

Iino, Y. and M. Yamamoto. 1985. Mutants of Schizosaccharomyces pombe which sporulate in the haploid state. Mol. \& Gen. Genet. 82: 416-421.

Iino, Y., Y. Hiramine, and M. Yamamoto. 1995. The role of $c d c 2$ and other genes in meiosis in Schizosaccharomyces pombe. Genetics 140: 1235-1245.

Jimenez, G., J. Yucel, R. Rowley, and S. Subramani. 1992. The rad3 $3^{+}$gene of Schizosaccharomyces pombe is involved in multiple checkpoint functions and in DNA repair. Proc. Natl. Acad. Sci. 89: 4952-4956.

Jin, P., Y. Gu, and D.O. Morgan. 1996. Role of inhibitory CDC2 phosphorylation in radiation-induced G2 arrest in human cells. J. Cell. Biol. 134: 963-970.

Kato, R. and H. Ogawa. 1994. An essential gene, ESR1, is required for mitotic cell growth, DNA repair and meiotic recombination in Saccharomyces cerevisiae. Nucleic Acids Res. 22: 3104-3112.

Keegan, K.S., D.A. Holtzman, A.W. Plug, E.R. Christenson, E.E. Brainerd, G. Flaggs, N.J. Bentley, E.M. Taylor, M.S. Meyn, S.B. Moss et al. 1996. The Atr and Atm protein kinases associate with different sites along meiotically pairing chromosomes. Genes \& Dev. 10: 2423-2437.

Knudsen, K.E., E.S. Knudsen, J.Y. Wang, and S. Subramani. 1996. p34 ${ }^{\text {cdc2 }}$ kinase activity is maintained upon activation of the replication checkpoint in Schizosaccharomyces pombe. Proc. Natl. Acad. Sci. 93: 8278-8283.

Kumagai, A. and W.G. Dunphy. 1995. Control of the Cdc2/ cyclin B complex in Xenopus egg extracts arrested at a G2/M checkpoint with DNA synthesis inhibitors. Mol. Biol. Cell. 6: 199-213.

Kumagai, A., Z. Guo, K.H. Emami, S.X. Wang, and W.G. Dunphy. 1998. The Xenopus Chk1 protein kinase mediates a caffeine-sensitive pathway of checkpoint control in cell-free extracts. J. Cell. Biol. 142: 1559-1569.

Lindsay, H.D., D.J. Griffiths, R.J. Edwards, P.U. Christensen, J.M. Murray, F. Osman, N. Walworth, and A.M. Carr. 1998. S-phase-specific activation of Cds1 kinase defines a subpathway of the checkpoint response in Schizosaccharomyces pombe. Genes \& Dev. 12: 382-395.

Lundgren, K., N. Walworth, R. Booher, M. Dembski, M. Kirschner, and D. Beach. 1991. mik1 and wee1 cooperate in the inhibitory tyrosine phosphorylation of $c d c 2$. Cell 64: 11111122.

Lydall, D., Y. Nikolsky, D.K. Bishop, and T. Weinert. 1996. A meiotic recombination checkpoint controlled by mitotic checkpoint genes. Nature 383: 840-843.

MacNeill, S.A. and P. Nurse. 1997. Cell Cycle Control in Fission Yeast, Schizosaccharomyces pombe. In The molecular and cellular biology of the yeast Saccharomyces: Life cycle and cell biology. (ed. J.R. Pringle, J.R. Broach, and E.W. Jones), pp. 697-763. Cold Spring Harbor Laboratory, Cold Spring Harbor, New York, NY.

Matsuoka, S., M. Huang, and S.J. Elledge. 1998. Linkage of ATM to cell cycle regulation by the Chk 2 protein kinase. Science 282: $1893-1897$.

Moreno, S., A. Klar, and P. Nurse. 1991. Molecular genetic analysis of fission yeast Schizosaccharomyces pombe. Methods Enzymol. 194: 795-823.

Murakami, H. and H. Okayama. 1995. A kinase from fission yeast responsible for blocking mitosis in $\mathrm{S}$ phase. Nature 374: 817-819.

Nurse, P. 1985. Mutants of the fission yeast Schizosaccharomyces pombe which alter the shift between cell proliferation and sporulation. Mol. \& Gen. Genet. 198: 497-502.

. 1997. Checkpoint pathways come of age. Cell 91: 865867.

O'Connell, M.J., J.M. Raleigh, H.M. Verkade, and P. Nurse. 1997. Chk1 is a weel kinase in the G2 DNA damage checkpoint inhibiting cdc2 by Y15 phosphorylation. EMBO $I$. 16: $545-554$.

Peng, C.Y., P.R. Graves, R.S. Thoma, Z. Wu, A.S. Shaw, and H. Piwnica-Worms. 1997. Mitotic and G2 checkpoint control: Regulation of 14-3-3 protein binding by phosphorylation of Cdc25C on serine-216. Science 277: 1501-1505.

Rhind, N. and P. Russell. 1998a. Mitotic DNA damage and replication checkpoints in yeast. Curr. Opin. Cell. Biol. 10: $749-758$.

. 1998b. Tyrosine phosphorylation of cdc2 is required for the replication checkpoint in Schizosaccharomyces pombe. Mol. Cell. Biol. 18: 3782-3787.

Rhind, N., B. Furnari, and P. Russell. 1997. Cdc2 tyrosine phosphorylation is required for the DNA damage checkpoint in fission yeast. Genes \& Dev. 11: 504-511.

Robinow, C.F. 1977. The number of chromosomes in S. pombe: Light microscopy of stained preparations. Genetics 87: 491497.

Rockmill, B. and G.S. Roeder. 1998. Telomere-mediated chromosome pairing during meiosis in budding yeast. Genes \& Dev. 12: 2574-2586.

Roeder, G.S. 1997. Meiotic chromosomes: It takes two to tango. Genes \& Dev. 11: 2600-2621.

Rowley, R., S. Subramani, and P.G. Young. 1992. Checkpoint controls in Schizosaccharomyces pombe: rad1. EMBO I. 11: 1335-1342.

Saka, Y., F. Esashi, T. Matsusaka, S. Mochida, and M. Yanagida. 1997. Damage and replication checkpoint control in fission yeast is ensured by interactions of $\mathrm{Crb2}$, a protein with BRCT motif, with Cut5 and Chk1. Genes \& Dev. 11: 33873400.

Sanchez, Y., C. Wong, R.S. Thoma, R. Richman, Z. Wu, H. Piwnica-Worms, and S.J. Elledge. 1997. Conservation of the Chk1 checkpoint pathway in mammals: Linkage of DNA damage to $\mathrm{Cdk}$ regulation through $\mathrm{Cdc} 25$. Science 277: 1497-1501.

Sawin, K.E. and P. Nurse. 1998. Regulation of cell polarity by microtubules in fission yeast. J. Cell Biol. 142: 457-471.

Sazer, S. and S.W. Sherwood. 1990. Mitochondrial growth and DNA synthesis occur in the absence of nuclear DNA replication in fission yeast. J. Cell Sci. 97: 509-516.

Scherthan, H., J. Bahler, and J. Kohli. 1994. Dynamics of chromosome organization and pairing during meiotic prophase in fission yeast. J. Cell. Biol. 127: 273-285.

Sibon, O.C., V.A. Stevenson, and W.E. Theurkauf. 1997. DNAreplication checkpoint control at the Drosophila midblastula transition. Nature 388: 93-97.

Sorger, P.K. and A.W. Murray. 1992. S-phase feedback control in budding yeast independent of tyrosine phosphorylation of p34 ${ }^{C D C 28}$. Nature 355: 365-368.

Stuart, D. and C. Wittenberg. 1998. CLB5 and CLB6 are required for premeiotic DNA replication and activation of the meiotic S/M checkpoint. Genes \& Dev. 12: 2698-2710.

Stueland, C.S., D.J. Lew, M.J. Cismowski, and S.I. Reed. 1993. Full activation of $\mathrm{p} 34^{C D C 28}$ Histone H1 kinase activity is unable to promote entry into mitosis in checkpoint arrested cells of the yeast Saccharomyces cerevisiae. Mol. Cell. Biol. 
13: $3744-3755$.

Svoboda, A., J. Bähler, and J. Kohli. 1995. Microtubule-driven nuclear movements and linear elements as meiosis- specific characteristics of the fission yeasts Schizosaccharomyces versatilis and Schizosaccharomyces pombe. Chromosoma 104: 203-214.

Walworth, N.C. and R. Bernards. 1996. rad-dependent response of the chk1-encoded protein kinase at the DNA damage checkpoint. Science 271: 353-356.

Walworth, N., S. Davey, and D. Beach. 1993. Fission yeast chk1 protein kinase links the rad checkpoint pathway to $c d c 2$. Nature 363: 368-371.

Weinert, T. 1998a. DNA damage and checkpoint pathways: Molecular anatomy and interactions with repair. Cell 94: 555558.

- 1998b. DNA damage checkpoints update: Getting molecular. Curr. Opin. Genet. Dev. 8: 185-193.

Willson, J., S. Wilson, N. Warr, and F.Z. Watts. 1997. Isolation and characterization of the Schizosaccharomyces pombe rhp9 gene: A gene required for the DNA damage checkpoint but not the replication checkpoint. Nucleic Acids Res. 25: $2138-2146$.

Woods, A., T. Sherwin, R. Sasse, T. McRae, A. Baines, and K. Gull. 1989. Definition of individual components within the cytoskeleton of Trypanosoma brucei by a library of monoclonal antibodies. J. Cell Sci. 93: 491-500.

$\mathrm{Xu}$, Y., T. Ashley, E.E. Brainerd, R.T. Bronson, M.S. Meyn, and D. Baltimore. 1996. Targeted disruption of ATM leads to growth retardation, chromosomal fragmentation during meiosis, immune defects, and thymic lymphoma. Genes \& Dev. 10: 2411-2422.

Yamaguchi, S., H. Murakami, and H. Okayama. 1997. A WD repeat protein controls the cell cycle and differentiation by negatively regulating Cdc2/B-type cyclin complexes. Mol. Biol. Cell 8: 2475-2486.

Ye, X.S., R.R. Fincher, A. Tang, K. O'Donnell, and S.A. Osmani. 1996. Two S-phase checkpoint systems, one involving the function of both BIME and Tyr15 phosphorylation of $\mathrm{p} 34^{\text {cdc2 }}$, inhibit NIMA and prevent premature mitosis. EMBO $J$. 15: 3599-3610.

Zeng, Y., K.C. Forbes, Z. Wu, S. Moreno, H. Piwnica-Worms, and T. Enoch. 1998. Replication checkpoint requires phosphorylation of the phosphatase Cdc25 by Cds1 or Chk1. Nature 395: 507-510.. 


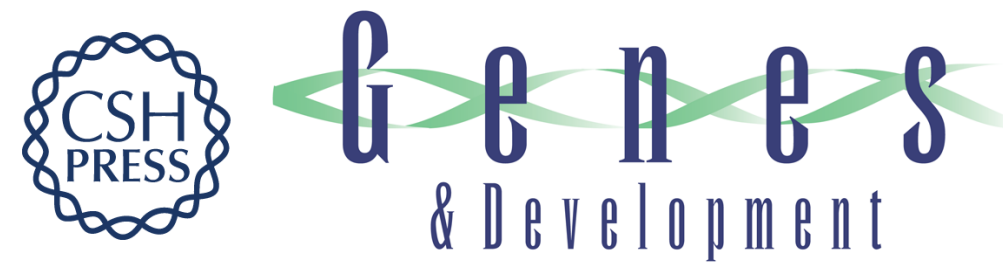

\section{Meiotic DNA replication checkpoint control in fission yeast}

Hiroshi Murakami and Paul Nurse

Genes Dev. 1999, 13:

References This article cites 71 articles, 41 of which can be accessed free at: http://genesdev.cshlp.org/content/13/19/2581.full.html\#ref-list-1

License

Email Alerting

Receive free email alerts when new articles cite this article - sign up in the box at the top Service right corner of the article or click here.

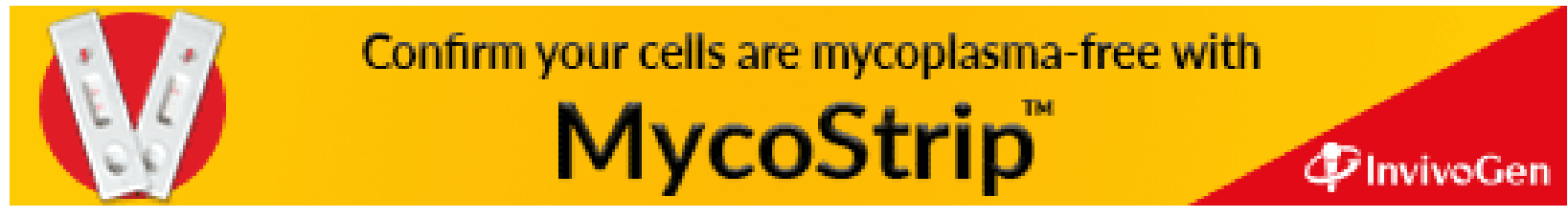

